\title{
A REVIEW ON ROLE OF FARMER ORGANISATION IN SRI LANKA: SPECIAL REFERENCE TO THE TEA SMALLHOLDING SECTOR
}

\author{
K.G.J.P. Mahindapala ${ }^{1}$,**, Jayathilaka M.W.A.P ${ }^{2}$ and Jayawardana L.N.A.C \\ ${ }^{1}$ Tea Research Institute of Sri Lanka,Ratnapura \\ ${ }^{2}$ Postgraduate Institute of Agriculture, University of Peradeniya, Sri Lanka
}

https://doi.org/10.35410/IJAEB.2020.5512

\begin{abstract}
Farmer-Based Organisations were formed to resolve the common problems faced by small-scale farmers through collective approaches. The FBOs has been categorised into two groups as community-based with resources oriented and commodity-based with market-oriented. There can be two different types of FBO, namely farmer organisations (FO) and farmer companies. This review attempted to discuss the status of the FOs in Sri Lanka while paying special emphasis on the tea smallholding sector in Sri Lanka. This review revealed that Farmer Organisations are not effectively operating in many sectors in Sri Lanka due to several reasons. This review exposed that like many other FO in Sri Lanka, Rural Tea Societies also mainly deal with inputs, government aids and heavily depend on extension service. These FOs do not involve in processing, value addition and marketing-related activities, and thus they can not be considered as market-oriented FOs.As community-based organisations, their production support activities are also not satisfactory with respect to many cases. These FOs do not engage in any For-Profit functions, and total financial gain received by the members are due to the selling of their primary products. Thus they are far behindthe status of Indian FPC and Agriculture Cooperatives in Japan.
\end{abstract}

Keywords: Farmer Organisation, Tea, Smallholder, Sri Lanka.

\section{INTRODUCTION}

Low capital and inadequate resources are common problems faced by smallholder farmers. They produce limited quantities that cannot generate comparative profits. The lack of access to the market, low bargaining power, lack of knowledge on agriculture technologies and poor infrastructure facilities are the other major issues they face, and Farmer-Based Organisations (FBO) were formed to tackle these issues. (Barham and Chitemi, 2009). The FBO has been described as an entitythat represents farmers in a given geographical area and deals with their agriculture enterprise-related needs (Esham, 2012). FAO defines FBO as voluntary membership organisations created for the economic benefit of farmers to provide services related to farming and marketing of their products. (Kassam et al., 2011).

According to the Esham (2012), There can be two different types of FBO, namely farmer organisation (FO) and farmer companies (FC). Depending on the size of the membership, nature of the service provided and level at which they function, FO can be small, medium or large scale 
and can be of the form of, (i) Farmer Interest Group (ii) farmer association/federation/Unions (iii) cooperatives (Kassam et al., 2011). The FBOs that are operating in the world has been categorised into two groups as community-based with resources oriented and commodity-based with market-oriented (Chamala and Shingi,1997). Fist type mainly deals with inputs and other resource needs of its members while the second type deals with commodities and more concern on value addition and selling their products in the competitive markets. However, in the present context, many FOs have a mixture of characters in relation to both groups.

In addition to poverty alleviation, FO can have many objectives. Scaling of economies, reduction of transaction and coordination cost, accessing to the capital, risk management and building up of countervailing power are some of the economic task expected. (Spileman and Bernard, 2009; Datta, 2004;Sallokhe,2016). Table 1 indicates the different roles played by FBO.

\section{Table 1: Servicers offered by various FO in the world}

\begin{tabular}{|ll|}
\hline Kind of benefits & $\begin{array}{l}\text { Description } \\
\text { Organising activity }\end{array}$ \\
Building capacities, Empowerment, Catalysing collective actions \\
Marketing service & $\begin{array}{l}\text { Inputs supply, Resources, Facilitation through collective activities } \\
\text { frocessing, Value addition, transporting of products, Wearhouse }\end{array}$ \\
Financial services & Loans and subsidies, promote savings, banking facilities \\
Technology services & Extension, Education, Training, Research activities \\
Welfare & Health, Livelihood support, Child education. \\
Management of resources & Irrigation water, Forest, Soil and Land, Fisheries \\
Policy advocacy & Provides inputs for policy formulation, act as a pressure group.
\end{tabular}

(Source: Adopted from Terebbin and Hassler, 2012; Rondot and Collion M, 2007)

This review attempted to discuss the status of the FBOs in Sri Lanka and to see how FOs have interacted with the issues in tea smallholding sector in Sri Lanka

The rest of the sections of this review will be organised in the following manner. Some of the successful scenarios will be discussed in part I. Part II provides a detailed account on Sri Lankan FBO in various settings. Part III is devoted to briefly discuss the issues in tea smallholding sector in Sri Lankaand attempt to see how FOs interact with them. Conclusive remarks are given in finally.

\section{Part I: Some examples of successful FBOs}

Farmer Producer Companies (FPC) in India and Agriculture Cooperatives in Japan are two examples for successfully operating FBOs in the Asia region. 
Vol. 5, No. 03; 2020

ISSN: $2456-8643$

\section{FPC in India}

Farmer Producer Companies (FPCs) in India have been established under the provision of company act of 1951 (amended in 2002). The main objective of this intervention was to establish an efficient FBOs in place of less active Farmer Producer Organisations (Cooperatives). This FPC is a hybrid of a private company and cooperative; Shareholders of this company are farmers; The company process the primary products and presented as a value-added product to the market, which is handled by the professional managers who have been recruited to the company.(Sharma, 2007; Terribin and Hassler 2012).

The initial capital of the company is generated through the sales of 'shares' to the farmers. Their liabilities are restricted to the 'shares'. The director board is appointed from the farmer's through their voting. In some cases, the external organisation provides the 'handholding support' for a certain period until they establish. (Salokhe, 2016). The primary objective of the FPC is to link the small farmers to the marketand ensure them to receive a better price. FPCs provide transportation, warehouse facilities, irrigation, inputs, extension service, production planning and branding of products (Terribin and Hassler 2012). In the context of FPC, the farmer's cost of production can be cut down through the bulk purchasing and transporting of inputs and also the farm productions to the market. Moreover, farmers can receive the better price through the various mechanism such as exposing for market information, vertical integration, developing more market relations, ensuring the market access, maintaining the food safety and quality standards (Ajmal et al.,(2018). By 2019 almost 2000 FPC have been established in all over India with the support of various Promoting agencies (NABRAD, 2019). These FPCs are diverse in terms of functions, working style and way they handle the issues and some are highly engaged in for-profit activities (Subash et al. 2019). Moreover, by analysing the market trends, Trebbin (2015) anticipated that professionally run and well-managed FPC would have greater opportunity to establish links even with international and multinational actors and enter into their supply chain.

\section{FBO in Japan}

Japanese Agriculture Cooperatives (JACs) popularly known as Nokyo, is the most widely spread FBO in Japan. JAC is considered as one of the most effective and efficient farmer organisation in the world (Rajarathna, 2007). The majority of the farmers in Japan have less than 1 ha. of holding, which pushed them to organise themselves into cooperatives. (Godo, 2009). Nokyo strengthens with 9.7 million members and Trillions of capitals. - i.e. funds handle its banking section and insurance arms itself is 88 and 47 trillion yen respectively and positioned in the $2^{\text {nd }}$ place in the banking and insurance trade. (Kazuhito, 2013). Since JAC has a sound cash flow, less likelihood of hindering the production processing as a result of a deficit of money. It is noteworthy that continuous growth is shown by the JAC, despitea declining trend appeared in the agricultural sector at national levels in most of the countries.

There are two important features in JAC. The majority of the farmers who distributed all over the country is a member of the JAC. The JAC covers most of the economic and welfare needs of the farmers such as financing, insurance, marketing, processing, value addition, purchasing of inputs, welfare, technology transfer. Therefore, it is an example for an integrated service 
model(Esham, 2013). When we look at the JAC structure, it is a three-tiered hierarchical structure. Its basic unit consists of primary cooperatives operated at the local level. The next level of the hierarchy is at the prefectural level composed of prefectural federations and are formed according to functional areas. The top of the hierarchy is the national federation and that also organised based on the functional aspects. The primary cooperatives are two types, and they can be either farming type or multipurpose type. 'Central Union' is the apex body of the entire system, and it monitors the primary cooperatives. In addition to the management function, the subject areas of Agriculture extension, policy planning and development, are entrusted with the central union. The various national-level federations handle different functional areas (Esham, 2013). JAC employ high calibre expertise to manage the institutions.

Primary cooperatives are composed of two types of members such as regular members and associate members depending on the type of cooperatives. Regular members are the person who engages with farming activities, and associate members are non- farmers. Therefore, the agriculture cooperatives are made out with farmers' whereas both regular and associate members can be present in the multipurpose cooperatives and which facilitate later one to go for diverse business. Both types of members could enjoy the same type of benefits based on their contribution, and they have privileges to access to all the services offered by JAC, except voting rights and electing to the managerial positions which are not entitled to the associate members (Esham, 2012). Existence of JAC is significant not only for the members but also for Japanese economics as a whole. (Yujiro and Yamada, 1991).

Collective group action, leadership, commitment, community mobilisation, participatory decision making, the process of value addition, marketing of product are the key elements contributed to the success the JAC (Paget- Clerk, 1999). JAC, able to effectively cater to the membership needs such as a supply of inputs, market information, facilitate in marketing, technological support, financial support, and that lead to higher participation of members for collective action. (Rajarathna, 2007).

With that background, let us attempt to examine the role of FBO in Sri Lanka comparatively.

\section{Part II: FBO in Sri Lanka}

\section{FBO in the non-plantation sector}

In Sri Lanka, the history of FBO goes back to the early $20^{\text {th }}$ century; first, they were emerged as thrift and credit society to help the small farmers when they need financial support. Later they were evolved into cooperative societies and formally supported for farming activities.FOs were first formally recognised by the agrarian service act in 1958 (which later repealed by act no.58 of 1979) and under the provision of said act, Agrarian Servicers Department was authorised to monitor the FOs. Before the 1980s, $80 \%$ of the rural people were farmers and, the government more relied on agriculture as a tool for rural development. However, FOsdid not properly deal with the challenges that had faced due to poor leadership, poor attitudes, ideological conflicts of cultural and religious, political influences and structural matters (Rajarathna, 2007).Yet, in the first time of the history, Farmer Organization component was included into the agriculturerelated project known as Gal OyaWater Management Project implemented in 1979 jointly by 
Irrigation Department (ID) and Agrarian Research and Training Institute(ARTI), funded by USAID. This attempt was used as a pilot study to test some of the concept and strategies related to the FO, which haslater been implemented in the major irrigation schemes (Geragama et al. 1999). The above Agrarian services act was amended in 1991 (no. 4 of 1991)and legislative provisions were provided to register all the FO in the non-plantation sector. Geeragama et al., (1999) reported that there were 1746 registered FO in Anuradhapura and Matale district. In later many FOs were evolved in different sub-sectors which were promoted by state agencies such as Department of Agrarian Services, Department of Agriculture, Department of Irrigation as well as private organizations. Rajarathna estimated that by 2007 , there were about $15,000 \mathrm{FBO}$ in the various part of the country. It is interesting to note that some private agenesis also involved in promoting FBO,especially among the contract farmers. In such cases those FBOs act as intermediaries between farmers and Agribusiness companies.

In the Sri Lankan context, there are three types of FBO can be observed, and they are Farmer Interest Group (FIG), FO and Farmer companies (FC). FIGs often integrated into FO but some occasions remained as it is. The FOsare managed by the executive committee, which consists of President, secretaries, Two vice presidents, treasurer and few committee members (Esham, 2012). Although legal provisions were granted to establish the links with relevant organisations (i.e. District development committee) in order to strengthen themselves, they have hardly made use such provisions (Rajarathna, 2007; Eshame 2007).

It was found that FO activities are significantly affected by the inefficiencies of relevant government officers (Gerragama et al., 1999). These FOs greatly depend on state agencies for various reasons such as extension, subsidies, regulatory matters etc. Therefore, activities of FOs are inevitably affected by the efficiencies of related state agencies. Having frequent farmer convention at the regional level with the participation of all the relevant state officials can narrow the gap between member farmers and also help to change their attitudes into the right direction (Geeragama et al., 1999). Further, Gerragama et al. (1999) suggested that developing of a federated structure at various level (i.e. Divisional level District level and national level) can also help to improve the efficiencies of these FOs. It appears that Sri Lankan FOs also stuck with the same challenges what Indian FPOs faced in the 90 s, such as poor governance, lack of accountability, financial constraints, and social loafing. (Borshtoem,2013; Datta,2004).

The Export Production Villages were established in the early 1980s under the government's concept of Peoples Company and considered as the first FC in Sri Lanka(Esham and Usami, 2007). The Export Development Board facilitated to link the rural producer with the export market. Subsequently, based on the recommendation given by the National Development Council of Sri Lanka in 1995, FCs were established in elsewhere by unifying the FOs within the particular region to enhance their bargaining power at the market place. The FC is an investorowned company established under company act and registered as Peoples Company to prevent any attempt for private ownership. (Esham, 2012)

In contrast with $\mathrm{FO}, \mathrm{FC}$ has a provision for enrollingnon-farmers as well to the membership as practiced by JAC, with a view to enhance the initial capital. However, that provision was restricted to the people who are residing in the same geographical area to prevent possible 
unnecessary implications. The FC is managed by the Board of Directors, appointed by the membership at the AGM. The number of Directors varies with the amount of share capital of the company, usually in the range of seven to twelve (Esham\&Usami 2007). In addition to the elected Directors, promoting agency also appoint few advisory directors, and the externally appointed team of management assisted them all. The membership is required to purchase the shares, but and anyone of them does not allow to purchase more than $10 \%$ of the shares. Shares can trade but solely among the members provided that it should not violate the $10 \%$ limit.

Under the concept of peoples' company, Department of Agriculture (DOA), Mahaweli Authority (MA), Irrigation Management Division (IMD) of Ministry of Irrigation, Export Development Board (EDB) have established the FC for different purposes. By the end of December 2003, 92 FC were resisted in the Registrar of company, of which the above state agencies directly involved in the initiation of 80 FC (Esham and Usami, 2007). Table 2 and 3give the details of FC promoted by different state agencies and few examples for the FC respectively.

Table 2: Details state agencies promoted by FC

\begin{tabular}{|c|c|c|c|}
\hline PA & No. of FC formed & Context of forming & Expected purpose \\
\hline DOA & 32 & $\begin{array}{l}\text { FIG belongs to FO comes under } \\
\text { Department of agrarian services } \\
\text { were transformed as FC }\end{array}$ & $\begin{array}{l}\text { The commercialisation } \\
\text { of agriculture products }\end{array}$ \\
\hline IMD & 8 & $\begin{array}{l}\text { Formed FC from FIG in the major } \\
\text { irrigation schemes. }\end{array}$ & $\begin{array}{l}\text { The commercialisation } \\
\text { of Outputs and } \\
\text { Irrigation }\end{array}$ \\
\hline MA & 4 & $\begin{array}{l}\text { FOs/federations in Mahaweli } \\
\text { scheme have been transformed as } \\
\text { FC }\end{array}$ & $\begin{array}{l}\text { The commercialisation } \\
\text { of Outputs and } \\
\text { Irrigation }\end{array}$ \\
\hline EDB & 36 & $\begin{array}{l}\text { Originated from rural people who } \\
\text { are engaged in agriculture-related } \\
\text { works }\end{array}$ & $\begin{array}{l}\text { Link the rural } \\
\text { producers with } \\
\text { international market }\end{array}$ \\
\hline
\end{tabular}

Source: Adopted from Esham and Usami 2007 
International Journal of Agriculture, Environment and Bioresearch

Vol. 5, No. 03; 2020

ISSN: $2456-8643$

Table 3: Examples for some FC promoted by state agencies.

\begin{tabular}{|lll|}
\hline Name of FC & Activities handled & Membership \\
Hiriyala FC & $\begin{array}{l}\text { Provide Inputs, credit facilities, Seed paddy } \\
\text { production }\end{array}$ \\
Ride Bendhi Ela FC & $\begin{array}{l}\text { Provide Inputs, credit facilities, Irrigation } \\
\text { Management, Contract Farming }\end{array}$ & \\
Elahera Mahaweli FC & $\begin{array}{l}\text { Provide Inputs, credit facilities, Irrigation } \\
\text { Management }\end{array}$ & \\
$\begin{array}{l}\text { Dambadeniya Export } \\
\text { Production Village }\end{array}$ & Manufacturing of Tea Packages & 1500 \\
\hline
\end{tabular}

Source: Adopted from Esham and Usami 2007

However, due to various reasons, these FC were unable to produce expected results, and some of them were collapsed. Political influences, poor managerial skills, lack of dignity of the board of Directors, poor monitoring and mistrust between management and the member farmers are the some of the possible reasons for failures (Senanayake,2002)

RidhiBendh Ela (RBE) is a good example for a relative success FC which is based in the irrigation scheme known as RidhiBendi Ela -a renovated ancient irrigation scheme located in Nikaweratiya DS division of North-western province. As a promoting agency, IMD, carryout several activities including awareness of officials of the state agencies, convincing of farmer groups, training, the intervention of share issuing, appointing of the board of directors, staffing, registration as FC, preparation and signing of MOU, implementing of works (Hussain and Perera, 2004). Furthermore, Esham\&Usami (2007) intensely studied RidhiBendi Ela (RBE) FC and found that significant financial progress has been achieved and FC made a considerable impact on irrigation management. However, its success in the area of commercialisation of agriculture products found to be limited due to failing in value addition and establishment of effective market linkages, lack of product diversification and poor awareness of the members due to the gap between FC and the farmers. The majority of the member perceived the FC as service providing agency, and Esham\&Usami (2007) argued that it is one of the preliminary barriers to go for far-reaching agribusiness. They suggested enhancing the share capital by enhancing the involvement of members by educating them as well as relaxing the restriction imposed for ownership for outsiders. Moreover, lack of federated structure as identified as one of the major deficiencies in the local FC system(Esham and Usami2007).In fact, NDC originally proposed a National level federation and under which several 'satellite FC' at the regional level, but failed in implementation (Hussain and Perera, 2004).

There are some similarities between Indian FPC and Sri Lankan FC in terms of the objective of forming and structure (Salokhe, 2016). However, the majority of the Sri Lankan FCs have not gone to the extent that most Indian FPC has gone. The lower outcome of the FC can be attributed to some drawbacks such as insufficient extension service to the members, lack of self-sustain 
capacity, lack of internal monitoring mechanism, poor links with high-end markets, poor management skills, lack of collective and Joint use approach, lack of participatory decision making, lack of diversity (many services under one roof)(Esham and Kobayashi, 2013). Further, Indian FPCs receive handholding support (Salokhe, 2016), whereas Sri Lankan FC doesnot receive comparable support.

\section{Fisheries Cooperatives}

Although some realities in the fisheries sector are dissimilar to the agriculture sector, in the point of view of social aspects, many things are common in both sectors. Therefore, by and large, the studies done on the cooperatives in the rural fishing sector can also be considered here. Cooperatives are widely spread in the coastal rural fisheries sector in Sri Lanka. There were 552 active cooperatives in the sector (NARA, 2008). The government mainly use these cooperatives to disburse the subsidies and other materials to the needy fishers (Amarasinghe, 2005).

By paying special attention to vulnerability and poverty, Amarasinghe and Bavnick (2007) attempted to study the crucial role of social capital in selected fishers cooperative in Hambantota district of Sri Lanka. They argued that through the formation of cooperatives, fishers are empowered as because of dealing with social capital. There are three forms of social capital, namely bonding capital, bridging capital and linking capital(Woolcock 2001). They further argued that this social capital help to members in the process of coping with poverty. Authors found that some cooperatives were lacking in bridging and linking capital while they were rich with bonding capital. The authors showed that the cooperative rich with all these capitals perform well.

Further, cooperative which was able to buildup relatively high social capitals has easy access for other forms of capital such as, financial, human and physical capital and which provide the resilience for the vulnerability of rural fishers. All the cooperative have equal opportunity to acquire the same amount of social capital, but it is not happening in the Sri Lankan fishers' cooperatives due to various reasons such as poor leadership, inefficient management, and a bad reputation (Amarasinghe and Bavnick 2007). Moreover, in addition to the issue of 'social capital,' the cooperatives may fail in delivering expected services due to political interference, mismanagement, poor structural arrangements. These cooperatives were registered under the provision of cooperative society act no.5 of 1972, and they are vertically tied with the state, and thus they are under the state bureaucracy. Further, these cooperatives deviate from the real definition of cooperatives and can affect the voluntary behaviour and self-reliance state. Although such limitations are there, Wanigasundara (2015) showed that there is a potential to effectively use the cooperatives in the development of Agriculture and fisheries sector in Sri Lanka.

\section{Farmer based organisation in the Plantation sector}

FOs in this sector have been established under the provision given by the variouslegislative acts.

\section{Rubber Sector}


FOs were established among the rubber smallholders under the provision of legislative act no 23 of 2000 and commonly called them as Thurusaviya Societies (TSS). The objectives of the societies are to increases the cooperation among the members, uplift the social and economic status of the members, promote the investment related to rubber industry, provide the financial assistance to the members, promote processing/value addition, marketing. The act has also provided the provision to establish 'Thurusaviya Fund' (TF) which is a government own statutory board to monitor these societies. These societies have a three-tier structure as rural level district level (for five districts) and national level. The district-level society comprises ofeach President, Secretary and Treasurer of the relevant rural level societies while, nationallevel societies comprise of eleven members from each district societies including President, Secretary and Treasurer. Although a federated structure has existed, district and national level societies appeared to be acted as linking agency with TF/state. Further, five out of thirteen director board members of TF Board of directors are appointed from Thurusaviya district society representatives. Although, more than $68 \%$ of the Rubber land belongs to the Tea smallholders and totals of 80,555 smallholders are available in the country (Anon, 2017a) only 20,000 smallholders are enrolled as members in the TSS. (Anon, 2011). Although there were 709 registered societies, across the rubber growing areas, only about $60 \%$ of them are active (Anon,2018). The main functions of the TSS are confined to very few activities such as running nurseries, establishment and maintaining of smokehouses and processing centres, running of collecting and primary product purchasing centres coordinating work for state subsidy programs and loans(Anon 2018). The main extension agencies in the rubber sector are Rubber Research Institute and Ruber Development Department, and it seems that these two institutions do not use TSSsin their extension process to reach the farmers. (Dissanayake, 2009; Riyaldeen, 2009). Although, TSSsundertake some sort of service is to the Rubber growers, whichis apparently not sufficient as per their mandate.

\section{i. Coconut Sector}

Similarly, Coconut development societies known as Kapruka Societies (KSs) were established under the legislative act no 31 of 2005. The structure of the Kapruka societies, assigned functions and objectives are almost similar to the TSS. However, their activities are not visible as none of the publication- even progress report or annual report was made available. Although Appuhamy (2009), emphasised the importance of formation and strengthening the FO in empowering the coconut growers, it appears that those two extension agencies (Coconut Cultivation Board and Coconut Research Institute) have not done any activity with KS. It seems that they are not active. Somarathnaet al. (2003), also assessed that these KSs have less capacity in managing the resource in Deduruoya basin.

\section{ii.Sugarcane Sector}

When it comes to the sugarcane industry, there is no any FO established under the provision of any legislative act. However, it was reported that a FO was established by Pelawatta Sugar Industries PLC (PSI) by releasing part of its land to a group of farmers comprises of 300 members(Perera, 2009), which is an example for private sector operating FO. The PSI provides the extension servicers and inputs to FO, and other needs of the members are looked after by FO. The members are supposed to provide the harvest to the PSI. Perera (2009) further, reported that 
in addition to this FO, two groups of registered contract growers were also operated by PSI and SevanagalaSugar Industries(SSI), and according to Esham, (2012) this kind of formal contract growing system affiliated to agribusiness enterprises can also be considered as FOs. The farmer members of this contract growing system have been assigned an equal extent of land for cultivation of sugarcane under a lease agreement. They were also offered a vast array of inputs such as planting material, fertiliser chemicals, machinery and irrigation water as well as services such as extension and transportation. Their output is purchased by relevant companies and compensate as agreed upon mutually. Hussain and Perera (2004) reported that these arrangements brought immense benefit to the farmers, which reflected in their productivity, household income and living standards. However, Keerthipla (2007), suggested transforming these systems into cooperatives to improve efficiency.

It is also clear that FBOs in these three sectors are also not doing a significant role for the betterment of their members. In the first and second part of this review, our attention is drawn to two successful application of FBO concept outside of the country as well as some different application within the country in various sectors and let us look at the tea sector.

\section{Part III: Role of FBOs in Tea Smallholding Sector in Sri Lanka}

Before, examine the present status of FBOs and their attainment to solve issues in the tea smallholding sector in Sri Lanka, it would be beneficial to have a brief account of the tea industry in Sri Lanka

\section{Tea Industry and Smallholding Sector in Sri Lanka}

Tea, being the main foreign exchange earning crop in Sri Lanka, provides greater strength to the national economy (bringing around 1.5 billion US dollarper year) and livelihood of people in tea industry while generating numerous benefits to the society (2017a). In terms of the size of holdings, three main segments could be identified in the Sri Lankan tea industry. They are smallholders, owning less than 10 acres (4 ha) of land, proprietary estates, owing toa land size between 10 - 50 acres (4-20 ha) and corporate sector estates having over 50 acres (20 ha) of land. Smallholders are the key contributors in the tea industry as they produce over $70 \%$ of the total production, and they hold over $60 \%$ of the tea land (Anon 2017b). The productivity of tea smallholding sector in Sri Lanka is $1872 \mathrm{~kg} / \mathrm{MT} / \mathrm{ha}$ and which is comparatively low when compared with Kenya and North India (Anon, 2016).

The Technology transfer mechanism and the development activities in the tea smallholding sector is handled by Tea Small Holdings Development Authority (TSHDA) which was established in 1977 under the act no 35 of 1975 and acts amended in 1991 (no 36) and 2003 (no.34). The extension mechanism in the smallholding sector mostly similar to the "Agriculture Knowledge System model", Where Tea Research Institute (TRI) does the research and TSHDA does the extension in the sector (Samansiri and Rajasinghe, 2009) and illustrates in Fig 3. 


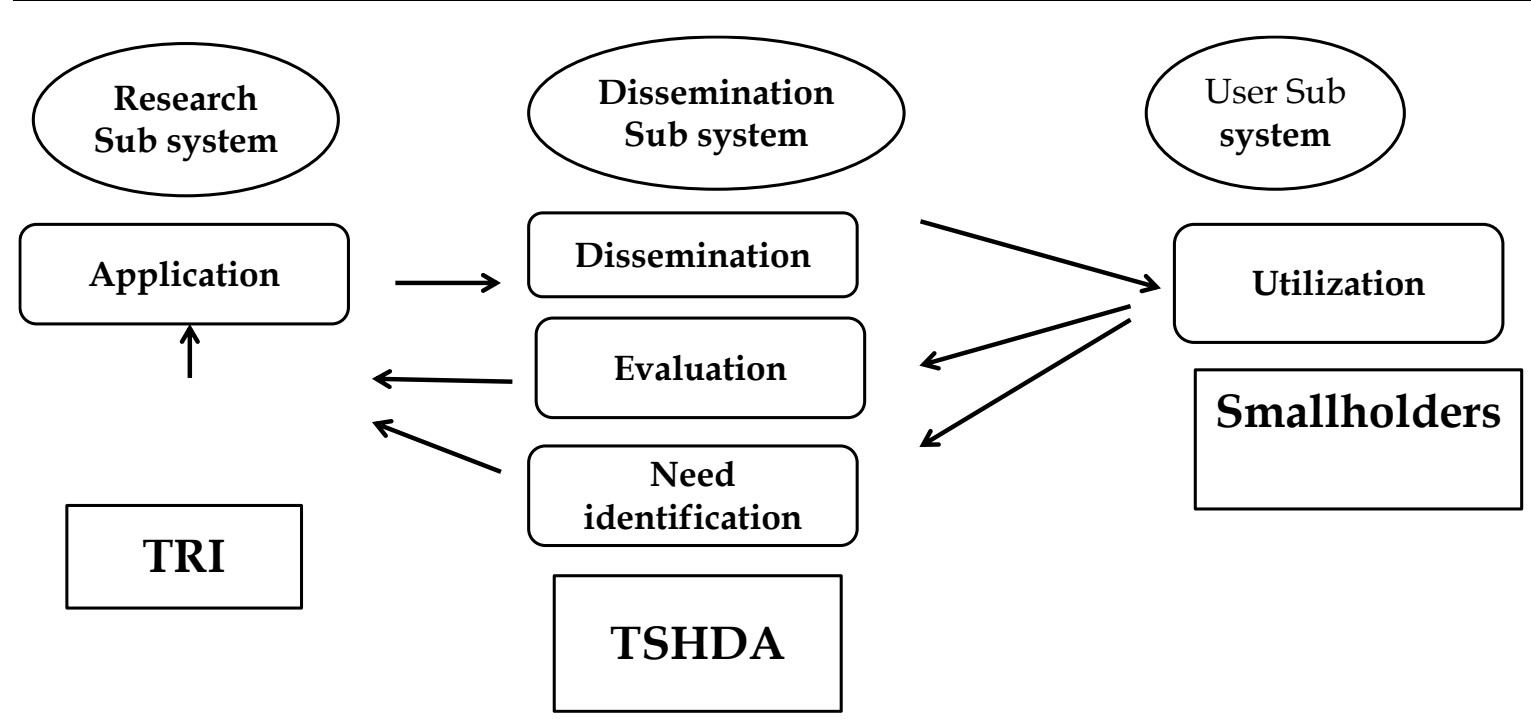

Fig. 3: Current extension mechanism in the smallholding sector

Source: Adopted from Samansiri and Rajasinghe, (2009)

Tea Inspector (TI) is the grassroots level extension worker, and he/she has to associate with tea smallholders in a certain geographical area (which is called TI range) (Obesekara 2009). However, there are only 157 TIs (Anon, 2017) to look after over 400,000 smallholders and which means that Extension Officer to Farmer ratio is over 1: 2700. This situation made TIs taskquite complicated as they are supposed to handle many functions (i.e. regulatory works, monitoring of financial aids) other than the extension activities. That cause to limit their actual time spends on extension works (Obesekara, 2009). Eventually, this condition developed into a severe gap between farmer and extension worker.

A study showed that smallholders in remote areas have minimum access to government extension services (Perera, 2014). This will not only affect the delivery of technical content but also affect the motivating the farmers towards the technology adoption which can affect the adoption of technologies (Herath, 2010; Menozzi etal. 2015).

The adoption level of growers with respect to some of the cultural practices such as pruning, weed management, pest and disease management and soil moisture conservation is less than $60 \%$ in a study conducted in randomly selected three rural areas in Matara district, (Jayamannaet al., 2002). A sample survey conducted in TSHDA in 2008 revealed that $92 \%$ smallholders used old tea cultivars (TRI 2000 series), which introduced in the early 50s (Anon (2008b).

\section{FO and its Role in Tea Smallholding Sector}

In the backdrop of insufficient delivery of service, in 1989, TSHDA started to strengthen the FOs in the sector to utilise them for their extension activities(Obesekara, 2009). Furthermore, the government took initiatives to prepare the groundworks to form the tea societies by passing an 
amendment to TSHDA act referred to as no 36 of 1991 and no. 21 of 1997. Subsequently, rural tea societies were systematically established and registered in the TSHDA based on the set of rules and regulations published in the gazette no. 878/15 of July 1995. In addition to the above legislative provisions, tea societies are abided by a constitution adopted in 2000 . These societies are established to achieve the following objectives (i) To develop tea smallholdings (ii) Provide the marketing facilities for growers production (iii) to promote the economic and welfare activities of members (iv) Facilitate the members in the area of credits and inputs (v) engage in development projects.

The entire Tea Smallholding Development Society (TSHDS) system looks like a federated structure with three tiers (fig.3). In the village level, there are a Rural Tea Societies (RTS), and there can be several RTS for any given Tea Inspector Region, depending on the number of tea growing GramaNiladhariDivison(Village level administrative unit) under each region and the holding density (Cyril, 2014).RTS is managed by an executive committee which comprises of President, Secretary and Treasurer and other eightrepresentative members appointed bi-annually from the members vote. The three main officers of each RTS in a particular district are combined to form the district level organisation. The National level organisation is made up with main officers of each district organisation, and table 4shows the details of societies in each district.

Fig. 3: Organisational structure of Tea societies(TSHDS) Note: 1- the strength of total membership. 2- Strength of management committee

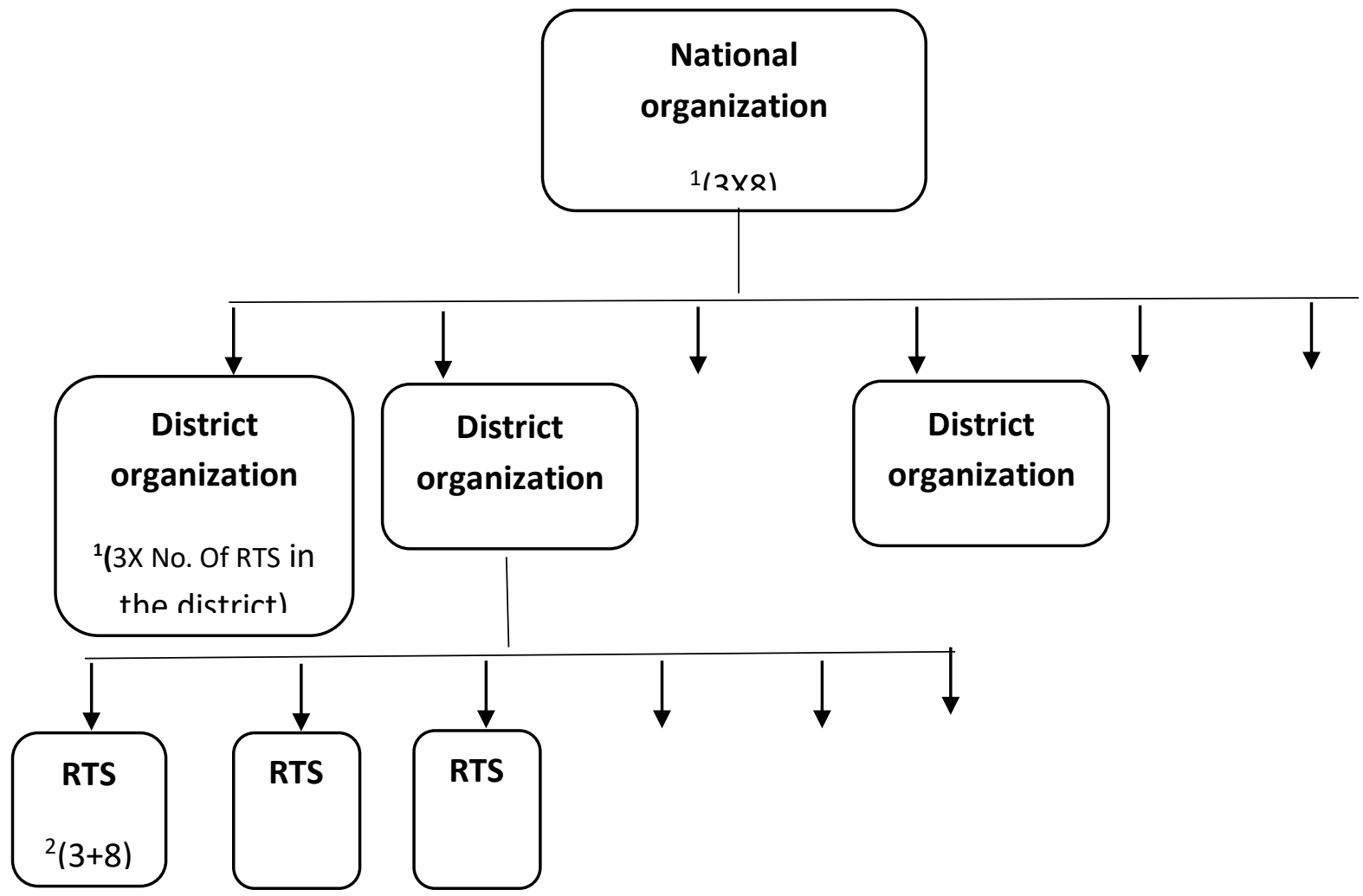

Source: Adopted fromCyril (2014). 
Table4: Details of societies in different regions

\begin{tabular}{|ll|}
\hline District & No. of RTS \\
Matara-Hambantota & 166 \\
Galle & 208 \\
Kalutara & 89 \\
Ratnapura & 273 \\
Kegalle & 119 \\
Kandy- Matale & 133 \\
Badulla & 156 \\
Total & 1319 \\
\hline
\end{tabular}

Source: Obeysekara, (2009)

TIs are closely associated with RTSs and required to monitor their activities.

An organisation known as Tea Shakthi Fund (TSF) had been established to develop the entrepreneurship of RTS members and reinforced with their shares. However, now it has collapsed.

There were not many studies done about TSHDS. However,Bandula et al. (2016), has done a study to evaluate whether these societies were able to make any quantifiable impact on tea smallholders in Matara district. Their findings revealed that there is no significant improvement in tea smallholding sector in the study area because of the introduction of TSHDSs. This finding is negating the positive results on FBOs seen in the Indian and Japanese context. The particular study further revealed that only $27 \%$ of the members are satisfied with their activities. However, majority of both members, as well as non-members (75\% and $85 \%$ respectively), were of the opinion that RTS could be transformed as a productive entity which can make an impact on their lives and which indicated that there is some problem lies with the RTS. According to the results, the majority of the members look the RTS as a means of facilitating body for channelling the subsidies and advice, and they do not perceive the other advantageous of FOs.

Mahindapala et al. (2020) found that the majority of RTS are not performing well due to certain internal and external factors. Internal factors were identified as poor leadership, lack of commitments of members, issues in trustworthiness, status and attitudes of the members, while external factors are urbanisation of rural areas, government assistance, the role of the extension agent, the effect of other organisation and politics. In the same study, it was revealed, that the self-reliance status of the RTS is poor as they mainly depend on TIs and highly sensitive to the government aids. The majority of RTSs are not goal-oriented, and none of the organisation involved in value addition, processing and marketing. 
In that context, it is doubtful that TSHDS system is able to achieve the expected objectives. If it is so,the smallholding tea industry should be in a better position today. Some indicators are also supported to the above findings. TSHDA has never been able to achieve the minimum replanting target (rate of $2 \%$ ) even after the establishment of the society (Anon, 2008b, 20092010, 2011b, 2012-2015, 2015c, 2016b, 2017b). As shown in table 5, there has not been seen as a significant improvement in the other key indicators over the past 15 year's period. The development role expected through the societies appears to have failed to realise.

Table 5: Performance indicators in the smallholding sector in 2007 and 2017

\begin{tabular}{|llllll|}
\hline Year & Productivity & Production & $\begin{array}{c}\text { Indicator } \\
\text { Replanting }\end{array}$ & Infilling & Extent \\
& (kg/ha/year) & (million kg) & (ha) & (ha) & (ha) \\
2007 & 2039 & 224.8 & 1024 & 41.28 & 119,492 \\
2017 & 1995 & 232.4 & 748 & 45.13 & 116,492 \\
\hline
\end{tabular}

Source: Annual reports TSHDA 2008 and 2017

As shown in the above, TSHDS did not engage in 'For Profit' business activities. Nevertheless, that does not mean that 'For-Profit' approach is inappropriate or impossible. It is noteworthy that, all 'C type' FPC in India are For-Profit entities (Terabbin, 2014). Moreover, Kenyan Tea Development Agency is the tea smallholders owned organisation in Kenya and which functioned as Farmer Company and engaged in processing and value addition of tea (KHRC, 2008; Monroy et al., 2013).

Development of the smallholdings is one of the objectives of the establishment of TSHDS. Yet, it is not reflecting in the technology adoption levels of the majority of the growers. According to the recent studies, it was revealed that technology adoption of smallholders in the different region was at sub-optimal level (Mahindapala etal. 2019a, Mahindapala et al.2019b, Mahindapala etal. 2019c ). If society could have made an effective intervention, this would not have happened.

When realising the success stories of Indian FPC and Japanese Agriculture cooperatives, Sri Lankan TSHDS has greater opportunity to work although they have not attended. Therefore, it is inevitable to arise many questions regarding this. Why do these TSHDS systems fail to achieve success? Where have they gone wrong? What measures need to adopt to correct the system? We need to have more research work to answer these questions.

\section{CONCLUSION}

Although Farmer Organisations have been established in the agriculture field in Sri Lanka to empower the farmers, they are not effectively operating in many sectors in Sri Lanka due to several reasons including personal factors, organisational factors and external factors. This review exposed that like many other FO, in Sri Lanka, Rural Tea Societies also mainly deals with Inputs, Government aids and extension and do not involve in processing value addition and marketingmarketing-related activities, thus they can not be considered as market-oriented FOs. 
The production support process of RTSs as community-based organisations are also not satisfactory in many cases. These FOs do not engage in any For-Profit functions, and total financial gain received by the members isobtained from the sales of their primary products. Thus the status of these RTS is observed to be far behind when compared with Indian FPC and Agriculture Cooperatives in Japan. However, to enhance the status of these societies is prime important, and therefore, it is necessary to have more research work to investigate the related variables.

\section{REFERENCE}

Ajmal, Anees MP and Mathur, Aditi (2018) Journal of Pharmacognosy and Phytochemistry 2018; 7(6): 1321-1325

Amarasinghe O (2005) Modernisation and living standards of fishermen. In: Amarasinghe O (ed.) Modernisation and change in small-scale marine fisheries of Southern Sri Lanka. Navamaga Printers, Colombo, pp 315-357

Amarasinghe, O. and Bavnick, M., (2007), Building Resilience: Fisheries Cooperatives in Southern Sri Lanka (2011), In book: Poverty Mosaics: Realities and Prospects in Small-Scale Fisheries (pp.383-406), Springer Science+Business Media BV.

Anon, (2008a), A sample survey conducted by Tea Small Holding Development Authority.

Anon, (2011a) Annual report Thurusaviya Fund, Colombo

Anon, (2008b, 2009-2010, 2011b, 2012-2015, 2016b, 2017b) Annual Reports, Tea Small Holdings Development Authority, Sri Lanka

Anon (2016a), Annual report Sri Lanka Tea Board, Sri Lanka

Annon, 2017a, statistical Information of Plantation crops, Ministry of Plantation Industries, Battaramulla

Anon, 2017b Central bank Annual reports, Sri Lanka

Anon (2018), Annual report Thurusaviya Fund, Colombo

Appuhamy, PHAN (2009), Experience and Challenges in technology transfer in the Coconut Sector in Sri Lanka, Proceedings of AgricultureExtension conference, 2009 eds Civayoganadan, C., Published by Sri Lanka Agriculture Extension Asoociation.pp213-225

Bandula, G.G., Abeywickrama, L.M., De Zoysa, M (2016), Tea smallholders' perceptions and experience with tea smallholdings development societies (TSHDS) in Matara district of Sri Lanka, Tropical Agriculture Research and Extension. pp 222-227

Barham J, Chitemi C, 2009, "Collective action initiatives to improve marketing performance: lessons from farmer groups in Tanzania, Food Policy 34 pp53 - 59 
Vol. 5, No. 03; 2020

ISSN: $2456-8643$

Borhstoem, M., 2013. Effective cooperative governance: A practitioner's perspective. Journal of Co-operative Organization and Management. 1: 49-50.

Chamala, S. and Shingi P. M. (1997) Establishing and strengthening farmer organisations a reference manual, (Ed). Burton E. Swanson, BE) Published by Daya Publishing House New Delhi, 2005.

Cyril, M.B, (2014), Presentation Made on "Tea smallholding sector in Sri Lanka" at FAO IGG annual session, Rangoon, Indonesia

Datta S K, (2004), "Cooperatives in agriculture: philosophical and theoretical foundations of cooperatives", in State of the Indian Farmer A Millennium Study Government of India Ministry of Agriculture (Academic Foundation, New Delhi) pp 38 - 67

Dissanayake, A (2009) Experience and challenges of in extension of the Smallholder Rubber sector, Proceedings of AgricultureExtension conference, 2009 eds Civayoganadan, C., Published by Sri Lanka Agriculture Extension Association. Pp182-192

Esham, M. and Usami, K. (2007). Evaluating the performance of farmer companies in Sri Lanka: A case study of RidiBendi Ela farmer company. Journal of Agricultural Sciences, 3(2), pp. 86100 .

Esham, M. (2012), Lessons for Farmer Based Organisations (FBO) in Sri Lanka: Experiences from Agricultural Cooperatives (JA) in Japan A Journey in Harmony Sixty Years of Japan Sri Lanka Relations, Eds Karunaratne, H. D., University of Colombo and JAGAAS, pp 316-335

Esham M, Kobayashi H (2013), farmer companies in Sri Lanka: Lesson from agriculture cooperatives in Japan Sage Journals no4 (2), pp 117-133

Giragama, WMGB, Sanker MSSG, Samarakoon. SMA, (1999) Development and Strengthening of Farmer Organisations through Farmer Conventions: Final Evaluation Report on the Impact of Farmer Conventions held in Anuradhapura and Matale Districts, Research Study No. 104, Hector Kobbekaduwa Agrarian Research and Training Institute, Colombo, Sri Lanka

Godo, Y. (2009). The changing political dynamics of Japanese Agricultural Cooperatives. International Association of Agricultural Economists Conference Proceedings, Beijing, China.

Herath, CH, (2010), The Impact of Motivation on Farmers Decision Making on Technology Adoption with reference to Sri Lanka and the Czech Republic, 15th International Business Information Management Association Conference, at Cario Egypt.

Hussain, I.; Perera, L. R. 2004. Improving Agricultural Productivity through Integrated Service Provision with Public-Private Sector Partnerships. Working Paper 66. Colombo, Sri Lanka: International Water Management Institute

Jayamanna, V. S, Wijeratne, M. Wijayaratna C. M, (2002) Adoptability of New Technology in the Small-Holdings Tea Sector, Journal of Agriculture and Rural Development in the Tropics and Subtropics, Vol.103 n 02 pp 125-131 
Kassam L., Subasinghe R. Phillips M., (2011), Aquaculture farmer organisations and cluster management: Concepts and experiences - FAO fisheries and aquaculture technical paper, FAO, Rome

Kazuhito Y, (2013), Understand the Japan Agriculture Cooperatives, Politics Economy, available on http//nippon.com

Keerthipla, A.P., (2007)Sugar Industry of Sri Lanka: Issues and future challenges for development, Sugat tech, 9 (1) pp 1-10

KHRC, (2008), A Comparative Study of the Tea Sector in Kenya A Case Study of Large Scale Tea Estates Nairobi, Kenya, www.khrc.or.ke

Mahindapala, K.G.J.P, Jayarathna, S.P.A.P.K, Dayananda, H.N., Jayaweera, H. and Nishanthi, M.A.H. (2019a), Investigation of debilitation of tea and technology adoption in smallholders in Mathugama division in Kalutara district of Sri Lanka, Proceedings of $12^{\text {th }}$ International Research Conference of Kotelawala Defence University, Ratmalana.

Mahindapala, K.G.J.P, Jayarathna, S.P.A.P.K, (2019b), Technology adoption status and attributes of Tea bush debilitation in the smallholding sector in Deraniyagala divisional secretariat area, Proceedings of $75^{\text {th }}$ Annual Scientific session, Sri Lanka Association for Advancement of Science.

Mahindapala, K.J.G.P., Munasinghe, C.E., Jayaratna, S.P.A.P.K., Tharangika, H.B. and. Batheegama B.G.A.R.L. (2019c) Level of technology adoption and factors associated with tea bush debilitation in smallholdings in three selected ranges in Matara district, Journal of Agriculture and Value Addition, Vol.2 no.2 pp 72-83

Mahindapala, K.G.J.P. (2019d) Technology Adoption Status and Attributes of Tea Bush Debilitation in Smallholdings in Galle District. (Unpublished data)

Mahindapala, K.G.J.P, Jayathilaka, M.W.A.P, Jayawardane L.N.A.C, Kopiyawattage K.P.P. and De Mel M.P.M. (2020) Role and Capacity of Tea Societies in the Smallholding Sector in Sri Lanka: An Assessment Based on the Perceptions of Extension Officers. Tropical Agricultural Research, 31(1): 43-55.

Menozzi, D, Fioravanzi, M., Donati, M., (2015), farmer's motivation to adopt sustainable agricultural practices, Bio-based and Applied Economics 4(2): 125-147,

Monroy L., Mulinge W., Witwer, M., 2013. Analysis of incentives and disincentives for tea in Kenya. Technical notes series, MAFAP, FAO, Rome

NABARD (2019) Portal on Farmer Producers' Organizations. National Bank for Rural Development (NABARD), Mumbai, India. Available on https://nabfpo.in/images/staticFPO.html.

NARA 2008 Sri Lanka Fisheries Yearbook 2008, National Aquatic Resource Research and Development Agency, Colombo. 
Obeysekara K.G.B, 2009. Agriculture extension in the tea smallholding sector in Sri Lanka Proceedings of AgricultureExtension conference, 2009 eds Civayoganadan, C., Published by Sri Lanka Agriculture Extension Association Pp. 160-181

Paget-Clarke, N. (1998) Interview with Japanese Farmers' and Consumers' Cooperatives Representatives. http:// www.inmotionmagazine.com/jfcg.html Motion Magazine, August.

Perera, P., (2009), Tea Smallholders in Sri Lanka: Issues and Challenges in Remote Areas, International Journal of Business and Social Science, Vol. 5, No. 12 pp 107-117

Perera P. 2014, Tea smallholders in Sri Lanka: Issues and challenges in remote areas, International Journal of Business and Social Science Vol. 5, No. 12 pp107-117

Rajarathna, A.R., (2007), Roles and Effectiveness of Agricultural Cooperatives in Japan, with Special Emphasis on Organized Farm Activities, Journal of Developments in Sustainable Agriculture, Vol.2 pp192-198

Riyaldeen, F.R.M,(2009)Role of extension Towards the Sustainable Development in The Sri Lankan Rubber Industry. Proceedings of Agriculture Extension conference, 2009 eds Civayoganadan, C., Published by Sri Lanka Agriculture Extension Association. Pp193-212

Rondot P and Collion M-H, (2007) Investing in Rural Producer Organisations (RPOS) for Sustainable Agricultural Development. RPOs Limitation and World Bank Comparative Advantage, The World Bank, Washington, DC

Salokhe, S., (2016) Farmers producer organisation for effective linkage of small producers with the market, International Journal of Applied Research 2016; 2(10): 142-146

Samansiri and Rajasinghe, (2009) Agriculture extension in the tea plantation sector in Sri Lanka Proceedings of AgricultureExtension conference, 2009 eds Civayoganadan, C., Published by Sri Lanka Agriculture Extension Association. Pp139-159

Senanayake, MS, (2002) What is Ailing Farmer Companies of Sri Lanka in their Transformation into Successful Business Entities? Overview of Policy Issues, Paper presented at the 3rd International Conference of the Japan Economic Policy Association at Meiji University, Japan

Sharma V. P. (2007). India's Agrarian Crisis and Smallholder Producers' Participation in New Farm Supply Chain Initiatives: A Case Study of Contract Farming. IIM Working Paper No. 2007-08-01, Indian Institute of Management, Ahmedabad.

Somarathna P. G. (2003), Jinapala, K.; Perera, L. R.; Ariyaratne, B. R.; Bandaragoda, D. J.; Makin, I. 2003. Developing effective institutions for water resources management: A case study in the DeduruOya Basin, Sri Lanka., International Water Management Institute Working Paper 058 
Vol. 5, No. 03; 2020

ISSN: $2456-8643$

Spielman D.J and Bernard, T (2009) Reaching the Rural Poor through Rural Producer Organisations? A Study of Agricultural Marketing Cooperatives in Ethiopia, Food Policy, 34(1), pp60-9

Subash, S.P and Kumar, P.R. 2019. A case of a-IDEA: Technology Business Incubator in India. Country case study prepared for Workshop on Accelerating Agribusiness Startups Organised by Asian Productivity Organization, Tokyo, 11-15 March 2019, Yogyakarta, Indonesia

Trebbin, A. 2015, Producer Companies and Modern Retail in India-Current State and Future Potentials of Interaction, Organised retailing and agri-Business: Implications of the new supply chain on the Indian Farm Economy Eds. Rao N.C, Radhakrishna, Mishra, R.R., Kata K.V.R pp277-288.

Trebbin, A. and Hassler, M.,2012, Farmers' producer companies in India: A new concept for collective action?, Environment and Planning 44(2):411-427

Trebbin, A., 2014. Linking small farmers to modern retail through producer organisationsExperiences with producer companies in India. Food Policy. 45: 35-54.

Wanigasundera W.A.D.P. (2015), Status of Extension \& Advisory Services in Sri Lanka: Working Paper 1, Agricultural Extension in South Asia

Woolcock M, (2001) The place of Social capital in understanding social and economic outcomes. Can J Policy Res 6 (1). Government of Canada's Policy Research Secretariat, Ottawa

Yujiro, H. and Yamada, S. (1991). The agricultural development of Japan. University of Tokyo Press, Japan. 